[Agr. Biol. Chem., Vol. 30, No. 4, p. 345 350, 1966]

\title{
Studies on the Enzymatic Production of L-Aspartic Acid from Maleic Acid
}

\author{
Part II. Induction Effect of Malonic Acid
}

\author{
By Yoshichika Takamura, ${ }^{*}$ Iwao Kitamura, Minoru Iikura, \\ Kageaki Kono and Asaichiro OzAKI \\ Central Institute of Sanraku-Ocean Co. \\ Ooniwa, Fujisawa, Kanagawa Prefecture. \\ Received September 16, 1965
}

\begin{abstract}
It was found that malonic acid was replaceable for maleic acid which played an inductive role for the formation of the enzyme system concerned with the reaction of L-aspartic acid production from maleic acid.

The cells grown in the medium containing malonic acid showed a stronger activity of the above reaction than the cells grown on maleic acid. The induction effect of malonic acid was remarkable when the organism was cultured in an acid medium. Whereas, consumption of $\mathrm{C}^{14}$-malonic acid in the medium by the organism was not observed at all in any $\mathrm{pH}$ milieu even where the formation of the enzyme system essential for the reaction was fully conducted. It indicated that malonic acid penetrated preferentially in acid milieu into the cells was a non-metabolic inducer like thiomethyl- $\beta$-D-galactoside in $\beta$ galactosidase system and that permeability barrier might exist in the organism.

The formation of cis-trans isomerase which catalyzed the conversion of maleic acid to fumaric acid was much stimulated by the addition of either malonic acid or maleic acid. From these results, it was concluded that L-aspartic acid was produced from maleic acid and ammonium ion by both actions of the inducible cis-trans isomerase and the constitutive aspartase.
\end{abstract}

\section{INTRODUCTION}

Using resting cells of Alcaligenes faecalis 5-24, the production of L-aspartic acid from maleic acid and ammonium ion was reported in the previous paper, ${ }^{11}$ where it was revealed that this reaction was conducted only with cells cultured in the medium containing maleic acid. Maleic acid is then considered to be an effective inducer to form the enzyme system involved in this reaction. During the course of a further investigation, malonic acid was found to be replaceable for the inductive part of maleic acid and more effective than

\footnotetext{
* Department of Agricultural Chemistry, Faculty of Agriculture, University of Ibaragi

1) Y. Takamura, I. Kitamura, M. Iikura, K. Kōno and A. Ozaki., This Journal, 30, 338 (1966).
}

it. Then, a precise investigation on the effectiveness of maleic acid and malonic acid on their inductivity was carried out and the results are presented in this paper.

\section{MATERIALS AND METHODS}

Organism. Alcaligenes faecalis 5-24 was used thoughout the work.

Media and culture methods. The media and culture methods used in this work were described previously.

Preparation of cell-free extracts. Cells harvested at various time intervals from the cultured broth were suspended in phosphate buffer (1/15 M, pH 7.2) after once washing with water, and subjected to sonic oscillation with a sonic disintegrator for 10 min. in the cold. The supernatant solution obtained 
by centrifugation of the sonicated cell homogenate at 10,000 r.p.m. was used for enzyme assays.

Enzyme assays. Fumarase activity was evaluated from the consumption of fumaric acid which was spectrophotometrically determined based on the high ultraviolet absorption of fumarate at $240 \mathrm{~m} \mu$. Aspartase activity was measured through the production of L-aspartic acid from fumaric acid and ammonium ion.

cis-trans Isomerase activity was measured by the spectrophotometric method as described by Otsuka. $\left.{ }^{2}\right)$ The reaction mixture contained $0.2 \mathrm{ml}$ of sodium maleate $(1 / 500 \mathrm{M}), 0.5 \mathrm{ml}$ of enzyme solution, $0.5 \mathrm{ml}$ of pig's fumarase and $1.8 \mathrm{ml}$ of phosphate buffer $(1 / 15 \mathrm{M}, \mathrm{pH} 7.2)$ in a total volume of $3.0 \mathrm{ml}$.

Incorporation of radioactivity of $\mathrm{C}^{14}$-malonate. $0.2 \mathrm{ml}$ aliquot of the supernatant fluid was placed on a planchet and dried. The radioactivity was measured by Riken G.M.-counter. The counts observed were corrected for background radiation.

Chemicals. Sodium malonate $1-\mathrm{C}^{14}$ was obtained from Daiichi Kagaku Co., Tokyo. The specific activity was $9.32 \mathrm{mc} / \mathrm{mm}$.

Analytical Procedures. Analytical procedures were described previously.

\section{RESULTS}

1) Effect of organic acids on the induced synthesis the enzyme system.

Since maleic acid added to the basal medium accelerated remarkably the ability to produce

TABLE 1. SCREENING OF INDUCER

$\begin{array}{lcc}\begin{array}{l}\text { Compounds* added } \\ \text { to basal medium }\end{array} & \begin{array}{c}\text { Growth } \\ \text { (O. D.) }\end{array} & \begin{array}{c}\text { L-Aspartate } \\ \text { formed }\end{array} \\ \text { none } & .260 & 5.6 \% \\ \text { maleate } & .350 & 72.2 \\ \text { fumarate } & .282 & 6.2 \\ \text { citrate } & .380 & 5.7 \\ \text { pyruvate } & .337 & 6.6 \\ \text { CH } H_{3} \text {-maleate } & .286 & 6.0 \\ \text { malate } & .341 & 7.8 \\ \text { malonate } & .237 & 102.1 \\ \text { acetate } & .021 & -3.8 \\ \text { succinate } & .477 & 7.5 \\ \text { oxaloacetate } & .258 & 6.3 \\ \text { phthalate } & .275 & \end{array}$

* All compounds were added at a concentration of one per cent $(w / v)$.

2) K. Otsuka, This Journal, 25, 726 (1961).
L-aspartic acid from maleic acid and ammonium ion, a number of organic acids were screened to test the inducible effect on the synthesis of the enzyme system concerned. Various organic acids as described in Table 1 were added to the basal medium in the concentration of one per cent. Cells taken from $24 \mathrm{hrs}$. cultures were washed once with water, resuspended in distilled water and used as enzyme source for the production of L-aspartic acid from maleic acid.

As shown in Table $I$, the reaction to produce L-aspartic acid from maleic acid was rapidly carried out when cells cultured in media containing either maleic acid or malonic acid were used as enzyme sources. The induced synthesis of the enzyme system essential for the production of the amino acid was thus observed in both cells grown on maleic acid and on malonic acid, and the respective yields of L-aspartic acid produced enzymatically from maleic acid were 72 per cent and 102 per cent of the theoretical yield. Whereas, as shown in the table, the yields of the amino acid with other cells were very low. These results indicate that maleic and malonic acid, so far tested, have the ability to induce the synthesis of the enzyme system concerned and that malonic acid could accelerate this synthesis more remarkably than could maleic acid.

To find an optimal concentration of malonic acid in the medium for the enzyme system induction and to compare the induction effect of malonic acid with that of maleic acid, various concentrations of both organic acids in the medium were subjected to the investigation. Both maleic acid and malonic acid were added to the basal medium so as to give various concentrations as indicated in Fig. 1. Cells harvested at $22 \mathrm{hrs}$. were suspended in distilled water to a concentration of $20 \sim 22 \mathrm{mg}$ dry weight $/ \mathrm{ml}$ and used as enzyme source for the production of $\mathrm{L}$-aspartic acid. The results obtained are shown in Fig. 1. It is of interest that malonic acid is more 


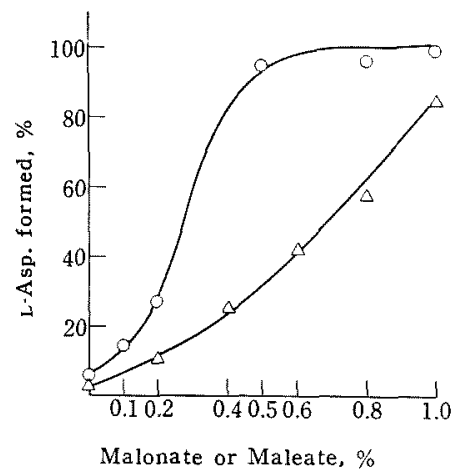

FIG. 1. Fffect of Concentrations of Malonate or Maleate in Media on the Enzyme Induction.

$$
\begin{aligned}
& O-O: \text { malonate-induced cell. } \\
& \triangle-\triangle: \text { maleate-induced cell. }
\end{aligned}
$$

effective than maleic acid on the induced synthesis of the system concerned. The maximum activity was obtained in cells harvested from the broth cultured in 0.5 per cent malonic acid medium. In contrast, when maleic acid was used as an inducer, the maximum activity was not reached even in the medium containing one per cent of maleic acid.

It is noticeable that malonic acid added to the basal medium can accelerate the induced synthesis of the enzyme system, because this acid is known to be generally non-assimilable in bacteria and rather a metabolic inhibitor in respiratory system of microorganism. Malonic acid in the medium, in fact, inhibited the growth of the organism to some extent, while maleic acid promoted it.

2) Effect of malonic acid added in the growing culture at different periods on the induced synthesis of the enzyme system.

Fig. 2. illustrates the effect of one per cent malonic acid added to the culture broth at different periods as indicated with arrows in the figure on the induced synthesis of the enzyme system. A good yield of L-aspartic acid was noted when malonic acid was added at earlier stage of the growth. The later the addition, the less the yield. The induced

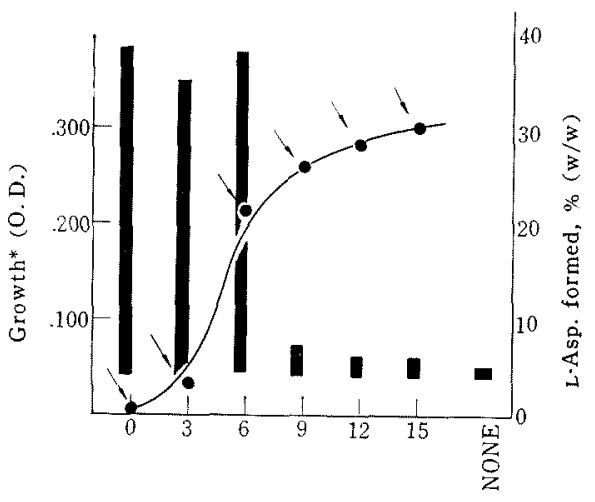

Time (hr)

FIG 2. Effect of Addition Time of Malonic acid on the Enzyme Formation.

- - Growth

$\leftarrow$ : Added of $1 \%$ Malonate.

L-Asp. formed from Maleic acid by the cell harvested after 22 hrs cultivation.

* Growth of the organism in the malonate-free medium.

synthesis of the enzyme system was not observed by the addition of malonic acid at the stationary phase of the growth where the cells were ceased to proliferate. It is then conceivable that malonic acid was well utilized as the inducer in the cells at earlier stage of the growth and that the induced synthesis of the enzyme system may be functioned, when the organism was proliferating logarithmically, by the presence of malonic acid.

3) Effect of $p H$ control on the induced synthesis of the enzyme system.

As reported previously, the induced synthesis of the enzyme system was notably accelerated by cultivating the organism in acid media which contained maleic acid as an inducer. Hence, the effect of $\mathrm{pH}$ control of the culture was investigated, employing malonic acid as the inducer instead of maleic acid. Cultivation was carried out in 201 jar fermenters, where $\mathrm{pH}$ of the culture was maintained in $\mathrm{pH}$ range of 6.4 to 6.9 throughout growth of the organism with auto-regulating addition of $1 \mathrm{~N}$ sulfuric acid. When $\mathrm{pH}$ was not controlled, the alkalinity of the culture was gradually increased and reached to 
TABLe II. EFFECT OF pH CONTROL ON THE ENZYME FORMATION

$\begin{array}{cccc}\text { pH control* } & \begin{array}{c}\text { Malonic acid } \\ \%\end{array} & \begin{array}{c}\text { Cell } \\ \text { Concentration acid formed }\end{array} & \begin{array}{c}\text { L-Aspartic } \\ -\end{array} \\ - & 0.5 & 6 \mathrm{mg} \text { dry wt/ml } & 13 \%(\mathrm{w} / \mathrm{w}) \\ - & 1.0 & " \prime & 56 \\ 6.4 \sim 7.0 & 0.5 & 2.6 & 99 \\ 6.4 \sim 7.0 & 1.0 & " \prime & 97\end{array}$

$\mathrm{pH} 8.8$ at the final $\mathrm{pH}$.

Table II summarizes the sequence of events in the production of $L$-aspartic acid when cells, cultured with or without $\mathrm{pH}$ control, were used as enzyme source. By controlling $\mathrm{pH}$, the induced synthesis of the enzyme was so markedly enhanced as to give the theoretical extent in the yield of L-aspartic acid. In contrast, the yield of the amino acid was very low with the cells dispensed with $\mathrm{pH}$ control, even in twofold cell concentration than that of the cells with $\mathrm{pH}$ control. The results indicate that $\mathrm{pH}$ control of an acid milieu favored the induced synthesis of enzyme essential for the reaction to produce L-aspartic acid from maleic acid. This phenomenon may result from promotion in penetration of malonic acid into the cell by an increase of hydrogen ion in the medium, similarly to the case of maleic acid induction.

4) Effect of initial $\mathrm{pH}$ of the medium on the consumption of malonic acid in medium.

Since it is expected that malonic acid added to the basal medium may be taken up the cells to induce the enzyme synthesis as in the case of maleic acid, changes in concentration of malonic acid in the medium during the the course of the growth were investigated employing $\quad 1-\mathrm{C}^{14}$-malonate. $1-\mathrm{C}^{14}$-Malonate was added to the basal medium together with carrier malonic acid so as to give one per cent in the total concentration, corresponding to approximately 4000 c.p.m. per $\mathrm{ml}$ culture medium in the radioactivity. Cultivation was carried out at different initial $\mathrm{pH}$ values, i.e. 5.9, 7.0 and 8.5. A small portion of culture
Table III. Change of the Concentration,op I-C14-MALONATE IN THE MEDIUM DURING THE Course of Cultivation

\begin{tabular}{cccccc} 
& \multicolumn{4}{c}{$\begin{array}{c}\text { I-G14-Malonate in the } \\
\text { c.p.m./0.2 ml }\end{array}$} \\
Initial pH & 0 hr. & 6 hrs. & 14 hrs. & 24 hrs. \\
& c.p.m. & c.p.m. & c.p.m. & c.p.m. \\
5.9 & 800 & 806 & 954 & 925 \\
7.0 & 800 & 760 & 825 & 916 \\
8.5 & 800 & 830 & 871 & 877 \\
medium: basal medium plus 1-C & 14-malonate $1 \%$.
\end{tabular}

broth was sampled out at several intervals and the radioactivity of the supernatant solution of it was measured by GM-counter. The results obtained are shown in Table III. Contrary to the expectation, it is apparently mentionable that malonic acid was virtually not consumed by the organism, though the induced synthesis of the enzyme system within cells was well accelerated by the addition of malonic acid and the production of $\mathrm{L}$-aspartic acid was fully conducted by these cells. It may be inquired, however, that a very small amount of malonic acid may be taken up by the organism to induce the enzyme synthesis, since it is impossible to estimate with radioisotopic method so small amount of malonic acid assimilated by the cell when carrier malonic acid was present too excess in the medium. Hence, the relationship between the incorporation of $\mathrm{C}^{14}$-malonic acid and the induction rate of the enzyme synthesis was investigated employing carrier malonic acid at various concentrations.

TABLE IV. INCORPORATION OF I-GI4-MALONATE

\begin{tabular}{lrrr}
$\begin{array}{c}\text { I-C14-Malonate } \\
\text { added }\end{array}$ & \multicolumn{2}{c}{$\begin{array}{c}\text { C14-Malonate in } \\
\text { medium }\end{array}$} & $\begin{array}{l}\text { 21 hr } \\
\text { Induction Rate } \\
\text { (L-Asp. formed) }\end{array}$ \\
$1 \%\left(9.6 \times 10^{-2} \mathrm{M}\right)$ & 903 & 1008 & $100 \%(\mathrm{w} / \mathrm{w})$ \\
$0.5\left(4.8 \times 10^{-2} \mathrm{M}\right)$ & 998 & 1027 & 100 \\
$0.2\left(9.6 \times 10^{-3} \mathrm{M}\right)$ & 1027 & 1135 & 28 \\
$0.1\left(4.8 \times 10^{-3} \mathrm{M}\right)$ & 1080 & 1176 & 12 \\
$0.05\left(9.6 \times 10^{-4} \mathrm{M}\right)$ & 1093 & 1186 & 5.2 \\
$0.01\left(4.8 \times 10^{-4} \mathrm{M}\right)$ & 1116 & 1170 & 4.9
\end{tabular}

* c.p.m. $/ 0.2 \mathrm{ml}$ broth supernatant. 
As shown in Table IV, the induction rate synthesis declined with diminution of the inducer malonic acid in the medium, but the radioactivity of $\mathrm{C}^{14}$-malonic acid in the medium was not changed at all even where fully induced cells were harvested. The organism cultured in the medium containing more than 0.5 per cent of malonic acid showed fully induced level of the enzyme activity and the enzymatic conversion of maleic acid to L-aspartic acid was rapidly performed by these cells.

It is also noticed that malonic acid added to the basal medium is hardly assimilated by the organism, while maleic acid was well assimilated to support the growth. (Table I).

It is of interest that a rather extracellular amount of malonic acid, over $0.5 \times 10^{-1} \mathrm{M}$, is indispensable for the organism to induce the enzyme synthesis although the amount of malonic acid actually taken up by the cells for the induction is too small to be detectable. From these results, it seems likely that no active transport system for malonic acid may function or exist in the organism.

6) Effect of maleic acid and malonic acid of the induced synthesis of cis-trans isomerase.

Two enzymes, cis-trans isomerse and aspartase, are possibly assumed to be involved in the reaction producing L-aspartic acid from maleic acid and ammonium ion. Since aspartase is rather constitutive enzyme in $A$. faecalis $5-24$, as reported previously, it is assumed that the acceleration of the ability by both malonic and maleic acids is closely related to the formation of cis-trans isomerase which catalyzes the conversion of maleic acid to fumaric acid. The activity of isomerase was assessed in cells grown on maleic acid, malonic acid and basal medium. As illustrated in Fig. 3, malonic acid and maleic acid exclusively accelerated the formation of isomerase. It is obvious that the enzyme is inducibly synthesized when the organism was cultured in the presence of either malonic acid or maleic acid. The activity of isomerase

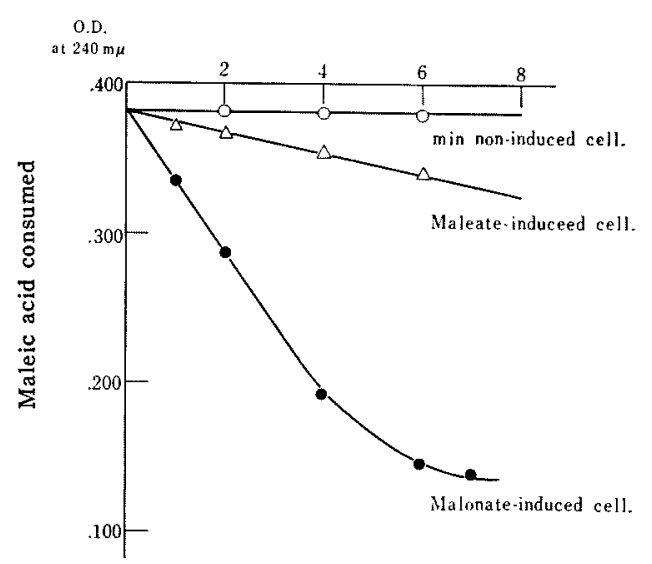

FIG. 3. Inducible Formation of Isomerase.

Reaction mixture: $0.2 \mathrm{ml}$ of sodium maleate $(1 / 500 \mathrm{M})$, $0.5 \mathrm{ml}$ of cell-free extracts, $0.5 \mathrm{ml}$ of pig's fumarase and $1.8 \mathrm{ml}$ of phosphate buffer $(1 / 15 \mathrm{M}, \mathrm{pH} 7.2)$ in a total volume of $3.0 \mathrm{ml}$.

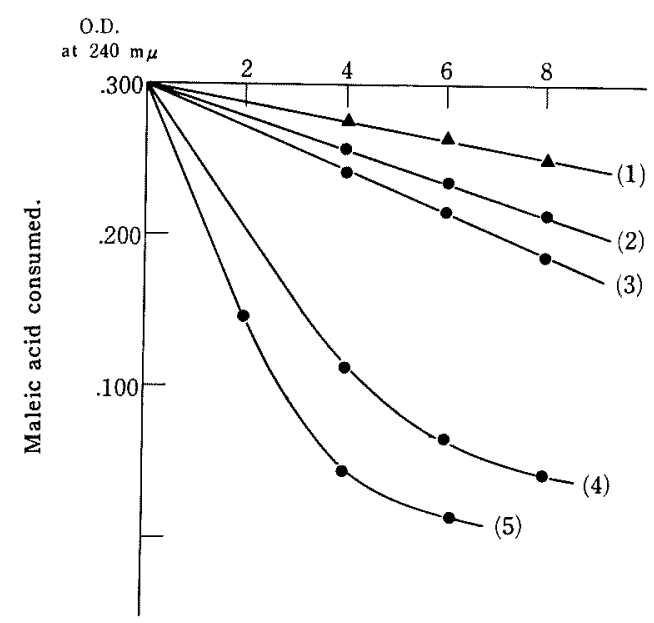

FIG. 4. Effect of Concentrations of Malonic Acid on the Induced Synthesis of Isomerase.

cell-free extracts were prepared from

(1) $1 \%$ maleic acid-induced cell, (2) $0.5 \%$ malonic acidinduced cell, (3) $0.75 \%$ malonic acid-induced cell, (4) $1 \%$ malonic acid-induced cell (5) $1.5 \%$ malonic acid-induced cell.

was the highest in the cell-free extracts of the cells grown in the medium containing malonic acid, corresponding to approximately five times than that of cell-free extracts of 
cells grown on maleic acid. The activity of cell-free etracts of cells grown in the basal medium was too low to be detectable. The rate of isomerization of maleic acid was increased in parallel with the increment of the concentration of malonic acid added to the medium and the ability of the cells to produce L-aspartic acid from maleic acid and ammonium ion was quite proportional to the activity of cis-trans isomerase in the connection with the malonic acid induction. (Fig. 4).

\section{DISCUSSION}

Malonic acid or maleic acid, as mentioned previously, could provide the cell with the ability to produce $\mathrm{L}$-aspartic acid from maleic acid in the presence of ammonium ion and also with the induced synthesis of cis-trans isomerase, while the synthesis of aspartase is not affected at all by the presence or absence of these acids. It is then suggested as already mentioned that two different enzymes, isomerase and aspartase, may be involved in the reaction to produce $\mathrm{L}$-aspartic acid from maleic acid. As the activity of malease was not observed in cell-free extracts of cells grown on malonic acid, the possibility of producing L-aspartic acid from maleic acid through malic acid as intermediate cannot be considered.

It is of interest that the synthesis of cis-trans isomerase was induced by malonic acid. Malonic acid is generally known as a competitive inhibitor of succinic dehydrogenase, while assimilation of this acid by bacteria is rarely found. In contrast to maleic acid, malonic acid is not utilizable for the cell growth in the tested bacterium and consumption of this acid from the culture medium during the growth is indiscernible, in spite of the fact that the induced enzyme synthesis is remarkably stimulated by external addition of this acid.

These results suggest that malonic acid which is scarcely assimilated by the organism may be a sort of "gratuitous inducer" like thiomethyl- $\beta$-D-galactoside (TMG) in $\beta$-galactosidase formation system, while maleic acid is a substrate inducer. It is noticeable that a large amount of malonic acid, $0.5 \times 10^{-1} \mathrm{M}$, is required for the cell to induce the synthesis of the enzyme as compared with only a small amount, $10^{-4} \mathrm{M}$, of TMG which is necessary for the induced formation of $\beta$-galactosidase. Necessity of such a large amount of malonic acid for the enzyme induction may be ascribed to the difficulty in the penetration of this acid into the cell.

Malonic acid is different in number of carbon from maleic acid and possesses in its chemical constitution a saturated linkage between two carboxyl groups. From such differences malonic acid may be conceived to be less reactive as an inducer than maleic acid. But, the reverse was the case and malonic acid was rather more effective than maleic acid.

Acknowledgement. The authors wish to express their sincere thanks to Prof. Teijiro Uemura, Institute of Applied Microbiology, the University of Tokyo, for his many helpful discussions and suggestions throughout this work. They are also grateful to Dr. Kenichi Otsuka, Research Institute of Fermention, Tax Administration Agency, Tokyo, for his guidance and encouragement in carrying out the experiment. 